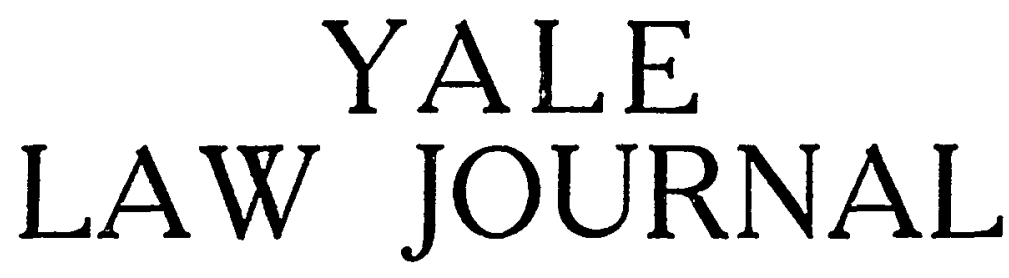

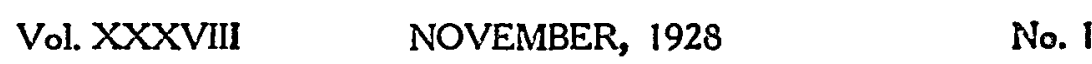

\title{
THIRD PARTIES AS BENEFICIARIES OF CONTRACTORS' SURETY BONDS
}

\author{
ARTHUR L. COREIN
}

The American Law Institute has tentatively adopted the two following general rules: ${ }^{1}$

"A gift promise in a contract creates a duty of the promisor to the donee beneficiary to perform the promise. This duty can be enforced by the donee beneficiary for his own benefit."

"A promise to discharge the promisee's duty [to another person] creates a duty of the promisor to the creditor beneficiary to perform the promise."

Around these statements is built up a system of other rules governing the relations of the beneficiary with both the promisor and the promisee. These rules represent the presently existing American law; but it has been arrived at only after more than a century of litigation, with an immense amount of conflict in decision and in the forms in which the law has been stated by the courts. These conflicting decisions and statements fill our reports and are still cited indiscriminately as authority, thus propagating further litigation and conflict.

It may seem unfortunate that the law of a great industrial democracy must be built up by such a slow, uncertain, and costly process; but the limitations of the human mind and experience appear to make it inevitable. It will be a vitally serious reproach to the science of jurisprudence, however, if the law cannot now be so stated as to avoid another century of conflict over the same issues. A well-trained lawyer should now be able to advise his clients with assurance and to save the economic waste of litigation. Every effort should therefore be made to improve and clarify the work of the Institute by constructive criticism, and to support its authority. This is particularly true in subjects where the existing conflict and uncertainty are not due

1 Contracts Restatenient (Am. L. Inst. 1926) $\$ \$ 135,136$. 
so much to differences of opinion on social policy as to mere complexity of legal relations and confused methods of analysis. Wherever a contract involves three or more parties instead of two, their legal relations increase by geometrical progression. This is the chief reason for the complexity, conflict and uncertainty in the law of suretyship and in the law of third party beneficiaries.

Parties affected by surety bonds. The giving of surety bonds to secure the performance of building and construction contracts, both public and private, is now a large part of the commercial surety's business. Such bonds create legal relations among at least four kinds of parties: (1) the owner for whom the construction work is being done-the direct obligee in the bond; (2) the principal contractor or obligor who is responsible for the construction work and who hires labor and buys material; (3) the laborers, materialmen, and subcontractors, whose work and material go into the construction; (4) the surety, who promises to answer for the defaults of the principal contractor. Still other parties than these sometimes attempt to secure advantages under the bond, but they will not be considered in this article. With the legal relations between the owner and the principal contractor, between the owner and the surety, and between the principal and the surety, we have at present nothing to do. They are the parties who make the contract and execute the bond. Our problem here is to determine the relations between the surety on the bond and the laborers, materialmen, and subcontractors. Does the bond create rights in these last named parties against the surety? Are they third party beneficiaries of the surety bond so that they can compel payment for their labor and materials by the surety?

These questions have already caused an immense amount of costly and unnecessary litigation. There is much apparent and some actual conflict among the court decisions, a fact that is bound to continue to breed more costly and unnecessary litigation. It is typical of our continuing struggle for law, a struggle for uniformity that can be used as a basis for future predictions, in a huge community with some fifty nearly independent jurisdictions. Simplicity and a greater degree of certainty can be achieved; but it will require the active efforts and co-operation of many jurists possessed of a high degree of political and judicial intelligence. The result can be achieved by clearly stating and regularly applying what is already the generally prevailing law, totally abandoning minority views not supported by the social interest, and frankly repudiating outworn dogmas.

We should now start with the general proposition that two contracting parties have power to create rights in a third party. This has long been a general rule; it is not an "exception." 
"Privity" is not necessary: the third party need not be a "promisee," nor need he give consideration. Secondly, it is not necessary to the creation of rights in the third party against the promisor that the promisee should owe any legal, equitable, or moral duty to the third party. This, also, las long been the prevailing rule; ${ }^{2}$ but there is a line of cases stating the contrary, ${ }^{3}$ though very often leeping the actual decision in hamony with it. And thirdly, the third party has an enforceable right if the surety promises in the bond, either in express words or by reasonable implication, to pay money to him. If there is such a promissory expression as this, there need be no discussion of "intention to benefit." We need not speculate for whose benefit the contract was made, or wonder whether the promisee was buying the promise for his own selfish interest or for philanthropic purposes. It is a much simpler question, did the surety promise to pay money to the plaintiff?

A "simpler" question, but not always a simple one. There will continue to be badly drawn bonds, although clarifying the law would tend toward improvement in draftsmanship. A fair share of the past litigation has been due to doubtful interpretation; such litigation cannot altogether be avoided. Nov is it meant that "intention to benefit" can be wholly eliminated from third party beneficiary law. It is merely asserted that in the case of a surety bond for the payment of money, if there is a promise to pay money to an ascertainable person, the fact that he is a third person who gave no consideration for the promise does not prevent him from enforcing it. The fact that he was not identified at the time of making the contract does not prevent him from being "ascertainable" at the time for performance.

Is a thind party's right dependcht on an intention to bcalefit him? The recognition of a right in a third person is often thought to depend upon the intention of the contracting parties, particularly that of the promisee who pays for the promise in question, to confer a benefit upon him. This has been variously expressed in scores of cases. ${ }^{*}$ But the ideas that lie behind such

${ }^{9}$ ANSON, CoNTRAGTS (Corbin's ed. 192\}) $\$ 298 ; 1$ Minliston, CoNtricis (1920) $\S 368$.

3 Vrooman v. Turner, 69 N. Y. $2 S 0$ (1S77); Jefierson v. Asch, 58 Minn. 446,55 N. W. 604 (1893).

* "It is not to be denied that the performance of the condition of the bond to Boyd would have worked consequentially a bonefit to Simson, if it had been performed by the payment of the $\$ 500$ and intercst to hirn. It might then be said, in a way, to have been a benefit to him in the exceution of it. But it is not every promise made by one to another, from the performance of which a benefit may ensue to a third, which gives a right of action to such third person, he being neither privy to the contract, nor to the consideration. The contract nust be made for his banefit 
terms as "purpose", "motive," and "intention" are obscure and elusive, as has been found in the criminal law as well as the civil.

as its object, and he must be the party intended to be benefited." Simson v. Brown, 68 N. Y. 355 (1877).

"According to good sense and upon principle there is no reason why a person may not maintain an action upon a contract, although not a party to it, when the parties to the contract intend that he may do so. Tho formal or immediate parties to a contract are not always the persons who have the most substantial interest in its performance. Sometimes a third person is exclusively interested in its fulfillment. If the partics choose to treat him as the primary party in interest, they recognize him as a privy in fact to the consideration and promise. And the result of the better considered decisions is that a third person may enforce a contract made by others for his benefit, whenever it is manifest from the nature or terms of the agreement that the parties intended to treat him as the person primarily interested." Austin v. Seligman, 18 Fed. 610 (C. C. S. D. N. Y. 1883).

"To entitle him to an action the contract must have been made for his benefit. He must be the party intended to be benefited." Garnsoy v. Rogers, 47 N. Y. 233 (1872).

"It must appear that the contract was made and was intended for his benefit. The fact that he is incidentally named in the contract, or that the contract, if carried out according to its terms, would inure to his benefit, is not sufficient to entitle him to demand its fulfillment. It must appear to have been the intention of the parties to secure to him personally tho benefit of its provisions." Sayward v. Dexter, 72 Fed. 758 (C. C. A. 9th, 1896).

"There must not only be an intent to secure some benefit to such third person but the contract must have been made and entered into directly and primarily for his benefit." Searles v. Flora, 225 Ill. 167, 80 N. E. 98 (1907).

"It seems equally clear to us that, whenever two parties enter into an agreement that appears to have been made expressly for the benefit of a third party, and such agreement has a good and sufficient consideration, the agreement itself creates all the privity there need be betweon the person-for whose benefit the agreement was entered into and the party assuming the obligation, and an action at law should lie regardless of whether there was any obligation existing between the othor party to the agreement and the third party. But, before the third party can adopt the agreement entered into and recover thereon, he must show clearly that it was entered into with the intent on the part of the parties theroto that such third party should be benefited thereby. This intent might, in a given case, sufficiently appear from the contract itself, but it must frequently be shown by other proof." Fry v. Ausman, 29 S. D. 30, 135 N. W. 708 (1912).

In Merchants Trust Co. v. Ummach, 228 Ill. App. 67 (1923), the court said: "It is not necessary that the obligation shall have been undertaken - . - directly or primarily for the benefit of the third person. The liability of the promisor to the third party . . . depends merely upon the question of whether the third party has a beneficial interest in the enforcement of the contract." This begs the question, in case by "boneficial interest" the court means a legal right; opinions not infrequently beg the question in this way. If by "beneficial interest" the court menns some factual interest other than a legal right, it is far too broad to be an accurate test. 
When a contract is made, the two or more contracting parties have separate purposes; each is stimulated by various motives, of some of which he may not be acutely conscious. The contract itself has no purpose, motive, or intent. The two parties have purposes, motives, and intentions; but they never have quite the same ones.

In third party cases, the right of such party does not depend upon the purpose, motive, or intent of the promisor. The motivating cause of his making the promise is usually his desire for the consideration given by the promisee. In few cases will he be moved by a desire to benefit a third person. If $A$ buys Blackacre of $B$ and promises $B$ to pay the price to $C$, he malies this promise in order to get Blackacre, not to benefit $C$; and this is true whether $C$ is a creditor of $B$ 's, or is $E$ 's dearly beloved daughter, or is a home for imbeciles. In determining the rights of a third party we can disregard the purposes and motives of the promisor, after we once determine that he has made a legally operative contract with his promisee.

How is it with the purposes and motives of the promisee? If $B$ conveys Blackacre to $A$ in return for $A^{\prime} s$ promise to pay $\$ 1000$ to $B$ 's dearly beloved daughter $C$, it will usually be a desire to make $C$ happy and comfortable that motivates $E$ and causes him to convey his land to $A$. There is a purpose and intent to "benefit" $C$ by making her a gift of money. This "intent to benefit" $C$ is given weight by the courts and the prevailing law is that $C$ has a right against $A$. Suppose, however, that $C$ is Shylock to whom $B$ owes $\$ 1000$ in life blood with compound interest. No love is lost on $C$ in this case; and yet $B$ makes the identical contract that he made above. $B$ conveys Blackacre to $A$ in return for $A$ 's promise to pay $\$ 1000$ to $E$ 's dearly hated creditor $C$. Here, too, the prevailing law is that $C$ has a right against $A$. It is certain that "intention to benefit" cannot be identified with love and affection. It is now a desire to escape from $C$ 's clutches that motivates $E$ and causes him to convey his land to $A$. Of course, a difference in legal result could be made between these two cases, giving $C$ a right against $A$ in the one case and not in the other; but such is not the prevailing law. ${ }^{5}$ Some courts have indeed made such a difference;

5 In Silver King Coalition MIfg. Co. v. Silver King Consol. $35 \mathrm{fg}$. Co., 201 Fed. 166 (C. C. A. Sth, 1913), the defendant had promised one who had trespassed on the plaintiff's mine to discharge all of the trespaczcr's obligation. The court realized that the contracting parties were in faet trying to defraud the plaintiff rather than to benefit it, but sustained a bill in equity to enforce the contract as a short cut to avoid cireuity of action. "In such a suit it is sufficient that the grantee has agrced with the grantor to be primarily liable for the latter's obligation to the creditor, so that, as between the parties to the agreement, the first is the principal and the second the surety. The creditor of the surety is then entitled in 
but they do not agree in the difference that they make. One court will hold that creditor $C$ has no right, because $B$ had no desire to "benefit" him, or because it would be unjust to make $A$ liable to two suits. ${ }^{6}$ Another court will deny a remedy to daughter $C$ because $B$ owed her no legal duty that would be discharged by the promised payment.

Since the prevailing law now is that $C$ has a right against $A$ in each of the above cases, they should be separately explained and not be alike based upon the indefinite phrase "intent to benefit." In both contracts alike, $A$ promised a specified performance. In both alike, $B$ desired that performance and paid

equity to be substituted in his place, and to maintain his suit against the grantee to the same extent as the grantor could have maintained it, and it is immaterial whether the contract was made and intended for the benefit of the creditor or of the grantor, for the creditor has all the rights of both to enforce the obligation of the grantee." In this case the court did more for the plaintiff than to put it in the place of tho promisee because the promisee could itself probably not have enforced the defendant's contract.

"Another exception is where the plaintiff is the beneficiary solely interested in the promise, as where one person contracts with another to pay money or deliver some valuable thing to a third. But where a debt already exists from one person to another, a promise by a third porson to pay such debt being primarily for the benefit of the original debtor, and to relieve him from liability to pay it (there being no novation), he has a right of action against the promisor for his own indemnity; and if the original creditor can also sue, the promisor would be linble to two separate actions, and therefore the rule is that the original creditor cannot sue." Second Nat'l Bank v. Grand Lodge, 98 U. S. 123 (1878). The same reasoning was used in Blymire v. Boistle, 6 Watts 182 (Pa. 1837).

Cases denying a remedy to a creditor beneficiary find it easy to do so, with an appearance of consistency with other decisions, by saying that the contracting parties did not make the contract for the benefit of the plain. tiff. See In re Gubelman, 13 F. (2d) 730 (C. C. A. 2d, 1926).

2 The case most often cited is Vrooman v. Turner, supra noto 3. Seo also Wilbur v. Wilbur, 17 R. I. 295, 21 Atl. 497 (1891); Jefferson v. Asch, suprä note 3; Dickinson v. McCoppin, 121 Ark. 414, 181 S. W. 151 (1015).

"To give a third party who may derive a benefit from the performance of the promise an action, there must be, first, an intent by the promisce to secure some benefit to the third party; and second, some privity between the two, the promisee and the party to be benefited, and some obligation or duty owing from the former to the latter which would give him a legal or equitable claim to the benefit of the promise or an equivalent from him personally. It is true there need be no privity between the promisor and the party claiming the benefit of the undertaking, neither is it necessary that the latter should be privy to the consideration of the promise, but it does not follow that a mere volunteer can avail himsolf of it. A legal obligation or duty of the promisee to him will so connect him with the transaction as to be a substitute for any privity with the promisor, or the consideration of the promise, the obligation of the promisce furnishing an evidence of the intent of the latter to benefit him, and creating a privity by substitution with the promisor." Vrooman v. Turner, supra. 
for it, although the antecedent motivating causes of his action were very different. In both alike, the performance would result in the direct pecuniary benefit of $C$, his benefit in the second case being a bird in the hand in place of one in the bush. In the one case it would come as a gift accompanied by love and affection and in the other case it would not. In both coses, $E$ contemplated the specific result that affected the interest of $C$ and "intended" that exact result. In both cases enforcement at the suit of $C$ would produce the "intended" result with the least amount of litigation and expense. The following is an attempt at a consistent statement of the generally prevailing law: a third party who is not a promisee and who geve no consideration has an enforceable right by reason of a contract made by two others (1) if he is a creditor of the promisee or of some other person and the contract called for a performanee by the promisor in satisfaction of the obligation; or (2) if the promised performance would be of pecuniary benefit to him, and the contract was so expressed as to give the promisor reason to know that such benefit was contemplated by the promisee as one of the motivating causes of his making the contract. A third party may be included within both of these provisions at once, but need not be. ${ }^{8}$ One who is included within neither of them has no right, even though performance will incidentally benefit him.

In a few cases the court has recognized the uncertainty of "intent to benefit" and has fallen back on doubtful distinctions in degree of benefit. Thus one court said, in a case that was well decided: ${ }^{3}$

"The test of the third person's right of action seems to depend upon the question as to whether the promise is made primarily for the benefit of the other party to the contract or of the third person, that is to say, whether the payment is in relief of the promisee and the fact that the money is to be paid to the third person is merely a matter of arrangement or convenience for the other party to the contract, or whether the primary purpose and object of the promise are to benefit the third

$s$ Although the right of a creditor beneficiary does not depend upon the intention of the promisee, there are cases where the intention to bencfit the creditor is obvious. In one case, by arrangement with the creditor, the promisee insured his life, with the creditor as beneficiary, in order to gire security to the creditor. Walton L. \& T. Co. v. Runyan, 260 Fed. 150 (C. C. A. 5th, 1920). The same may have been the arrangement in In re Newland, Fed. Cas. No. 10, 171 (S. D. N. Y. 1873).

In cases basing the right of a creditor beneficiary upon the "asset" theory or the "subrogation" theory, it is recognized that the right is not dependent upon any intention of the contracting parties to bencfit the third party. Silver King C. Mfg. Co. v. Silver King Consol. MIfg. Co., supra note 5 .

See Brill v. Brill, 282 Pa. 276, 280, 127 Atl. \$40, \$42 (1925). 
person. Of course, this distinction cannot exist in an absolute sense, because in every case there is presumably some benefit accruing to the promisee or else the contract would not have been so made and, on the other hand, there is also presumably some benefit accruing to the third person, by virtue of the fact that he is to be the recipient of the payment. But while, therefore, both the promisee and the third person no doubt receive some benefit in every such contract, the determining question is, whose interest and benefit are primarily subserved and as a matter of paramount purpose."

It is clear that if the "primary" and "paramount" purpose seems to be the benefit of the third person, as in the case of all sole and donee beneficiaries, he should have an enforceable right as the court says. But rights have not been limited so narrowly as this. In the case of most creditor beneficiaries, it is the purpose and intent of the promisee to procure the discharge of his obligation. The attainment of this end involves benefit both to himself and to his creditor. This "benefit" he intends to bring about as an entirety, having no idea in his own mind as to its division between the persons receiving it or as to "primary" or "paramount" purpose. Neither should the court make such a division. It should content itself with bringing about the entire result that the promised performance would attain. That result was the "paramount" object of desire and that result was the "primarily" intended result, including not only the ultimate end in view but also the means used to bring it about. The great majority of the courts attain this desired result in full by giving a remedy to the creditor against the promisor. The question is not "whose interest and benefit are primarily subserved," but what was the performance contracted for and what is the best way to bring it about.

There is a code provision in California and some other western states that a third person may enforce a contract if it was "made expressly for his benefit." This provision should not be held to require "express" words, either written or oral, that the promisee is motivated by a desire to confer a benefit upon the third person. The code provision is merely a provision attempting to express the modern common law empowering contractors to confer rights on third persons. It does not exclude creditor beneficiaries or attempt to state a formal line of distinction between intended beneficiaries and incidental ones. ${ }^{10}$

${ }^{10}$ In Goff v. Ladd, 161 Cal. 257, 118 Pac. 792 (1911); the facts wero these. The plaintiff sued $T$ and got judgment. $T$ gave an appeal bond with surety. The surety required and received the written promise of $T$ and $H$ that they "would pay such judgment as the court on appeal might award." The judgment was not paid, $T$ died insolvent and the surety is insolvent. It was held that the plaintiff could maintain suit against $H$ on his promise to the surety. Since it was not merely to reimburse the 
Classification of bond cases. The first irnportant classification is that dividing statutory bonds from non-statutory bonds.". The second is to divide the non-statutory bonds into those that promise to pay the third persons and those that do not. Less important classifications to which some attention must be given are those separating public construction contracts from private ones, and cases in which the third person has a power to create a lien on the obligee's property from those where he has not.

Common law surety bonds. The cases grouped in the note below are cases of non-statutory bonds where laborers, materialmen or other subcontractors were held to have a right to payment by the surety. ${ }^{12}$ The court believed that there was a

surety but was to pay the plaintiff's judgment, the court thought it was "made expressly for the benefit" of the plaintiff within $\$ 1559$ of the California Civil Code; and also, since it was sornething which the surety "received from the debtor by way of security," within $\S 2854$ of the Code, and hence available to the creditor.

In a state with a similar statute, where a shareholder sold shares and promised the buyer to lend the price to the corporation to be repaid only out of earnings, it was held that this was not so much for the beneat of the corporation that it could use it in defense in an action on notes for the money so lent. The contrary holding would have been better. Tatem v. Eglanol IIfg. Co., 45 ITont. 367, 123 Pac. 28 (1912).

II "IIuch confusion has resulted from the failure to distinguish batwcen statutory bonds for the completion of public worls of various linds and bonds securing the completion of private contracts. MIany cases fail, aleo, to distinguish the varying conditions contained in the bonds upon which suit is brought." Maryland Casualty Co. v. Johnson, 15 F. (2d) $\$ 258$ (W. D. MTich. 1926).

II Union S. II. Works v. Dodge, 129 Cal. 390, 62 Pac. 41 (1900) ; Board of Education v. Chicago Bonding \& Sur. Co., 21s Ill. App. 20 (1020); Knight \& Jillson Co. v. Castle, 172 Ind. 97, S7 N. E. 976 (1908) scmblo; Ochs v. Carnahan Co., 42 Ind. App. 157, 76 N. E. 78s, s0 NN. E. 163 (1908) (conditioned "and shall pay for all material and all holp"); Nat'l Surcty Co. v. Foster Lumber Co., 42 Ind. App. 671, 85 N. E. 489 (1903); King v. Downey, 24 Ind. App. 262, 56 N. E. 680 (1899); Williams v. MLariland, 15 Ind. App. 669, 44 N. E. 562 (1896); Hay v. Hassett, 17.1 I0wa 601, 156 N. W. 734 (1916) (conditioned on "full payment of wages," statute authorizing suit on bond by any person "intended to be secured"); Gctehell MIfg. Co. v. Peterson, 124 Iowa 599, 100 N. W. 550 (1901); Hipwell v. Nat'l Sur. Co., 130 Iowa 656, 105 N. W. 318 (1906) (eity contract); Baker v. Bryan, 64 Iowa 561, 21 N. W. S3 (1834) (Echool district, ngt necessary that the plaintiff should have given credit in reliance on the bond); Algonite IIfg. Co. v. Fidelity \& D. Co., 100 Kan. 2S, 163 Pac. 1070 (1917) (conditioned merely on performance of contract which provided that contractor should pay all laborers and materialmen); American Fid. Co. v. State, 128 IId. 50, 97 Atl. 12 (1916); National Sur. Co. v. HallMiller D. Co., 104 Miss. 626, 61 So. 700 (1918); LaCrozse L. Co. v. Schwartz, 163 IIo. App. 659, 147 S. W. 501 (1912); Eufalo Forge Cu. :. Cullen \& Stock Mifg. Co., 105 Mo. App. 4S4, 79 S. W. 1029 (1904) (bond provided principal should pay all laboiess and matwialmen); Itact $x$ Howard, 144 No. 671, 46 S. W. 625 (1S98) (city contract); St. Louis v. Von Phol, 133 ITo. 561, 34 S. W. S18 (1S96) (bond provided that it 
promise to pay the third party, although in some cases it was expressed in the form of a "condition" and in others it was found only by a liberal interpretation of the bond along with the construction contract. The cases cited include both public construction contracts and private ones.

A surety bond that is conditioned on full performance of his contract by the principal, will operate in favor of such third parties as the principal, by his contract with the promisee, undertakes to pay; the bond need be no more specific. ${ }^{13}$ The surety bond may be broader in its terms than was required by the principal construction contract; but it is an independent contract and is enforceable according to its own terms. ${ }^{14}$ of course both contracts should be considered together if there is any doubt or ambiguity as to the interpretation of the bond. There are cases holding that third parties can enforce provisions in a bond, given to comply with a statutory requirement, that are in excess of those required by the statute. As to the excess, the effect of the bond is determined by the common law rules..$^{15}$

might "be sued on at the instance of any materialman, laboring man, or mechanic, in the name of the city"); Forburger Stone Co. v. Lion B. \& Sur. Co., 103 Neb. 202, 170 N. W. 897 (1919); Fitzgerald v. McClay, 47 Neb. 816, 66 N. W. 828 (1896) (state contract); Doll v. Crume, 41 Neb. 655, 59 N. W. 806 (1894); Lyman v. Lincoln, 38 Neb. 794, 57 N. W. 531 (1894) (city contract); Sample v. Hale, 34 Neb. 220, 51 N. W. 887 (1892) (state contract) ; Toner v. Long, 79 N. H. 458, 111 Atl. 311 (1920); Southwestern Port. Cem. Co. v. Williams, 251 Pace 380, 49 A. L. R. 625 (N. M. 1926); Guilford L. Mfg. Co. v. Johnson, 177 N. C. 44,97 S. E. 732 (1918); Orinoco S. Co. v. Shaw L. Co., 160 N. C. 428,76 S. I. 273 (1912) ; Gastonia v. Engineering Co., 131 N. C. 368,42 S. E. 858 (1902); Royal Indem. Co. v. Northern Ohio G. \& S. Co., 100 Ohio St. 373, 126 N. E. 405 (1919); Dolese Co. v. Chaney, 44 Okla. 745, 145 Pac. 1119 (1914) ; United States F. \& G. Co. v. Thomas, 156 S. W. 579 (Tex. Civ. App. 1913); M. H. Walker Realty Co. v. American Surety Co., 60 Utah 435, 211 Pac. 998 (1922) (suits by owner on bond given to company installing elevators); Yawkey C. L. Co. v. Sinaiko, 189 Wis. 298, 206 N. W. 976 (1926) (against an uncompensated surety on a private contract); Concrete Steel Co. v. Ill. Sur. Co., 163 Wis. 41, 157 N. W. 543 (1016) (conditioned "shall satisfy all claims and demands"); Connor Co. v. Aetna Indemnity Co., 136 Wis. 13, 115 N. W. 811 (1908) (public contract and promise obtained under mistaken belief that materialmen could havo lion); United States G. Co. v. Gleason, 135 Wis. 539,116 N. W. 238, 17 L. R. A. (N. S.) 906 (1908) (public building).

$V_{13}$ Fogarty v. Davis, 305 Mo. 288, 264 S. W. 879 (1924).

14 National Sur. Co. v. Hall-Miller Dec. Co., 104 Miss. 626, 61 So. 700 (1913) ; Yawkey C. L. Co. v. Sinaiko, supra note 12.

${ }^{15}$ Puget Sound Bank v. Gallucci, 82 Wash. 445, 144 Pac. 698 (1914) (bank given judgment for money loaned to the contractor); Title Guarnnty \& S. Co. v. State, 61 Ind. App. 268, 291, 109 N. E. 237,111 N. E. 19 (1916) (the board of laborers); Hilton v. Universal Const. Co., 202 Mo. App. 672, 216 S. W. 1034 (1920); Clatsop Co. v. Feldschau, 101' Ore. 369, 
In any case where the third parties have an enforceable right as beneficiaries of the bond, the direct promisee in the bond has no power to discharge the surety's duty to them, whether by a release, by an extension of time to the principal contractor, by breaches of his own duties, or by agreeing upon changes in the principal contract. ${ }^{x 6}$ This applies only after the beneficiary has already become such by having extended credit to the principal contractor for labor or material within the terms of the bond.

The fact that the principal contract is illegal and void, because of the failure of the municipal promisee to comply with provisions of a statute or with cornmon law rules of nublic policy, will nullify the right of the third party to recover on the surety bond if he was a participant in or aware of the illegal conduct. ${ }^{17}$ If he was unaware of the illegal conduct he can

199 Pac. 953 (1921) (camp equipment and clothing for laborers); $c f$. also Philadelphia v. Nichols Co., 214 Pa. 265, 68 Atl. S\$6 (1906); Eristol v. Bostwick, 139 Tenn. 304, 202 S. W. 61 (1917).

"Plaintiff furnished labor and material and brought itself within the terms of the contract made by defendants. The undertalsing, if not c:pressly authorized by statute, was not prohibited. It was not against public policy or good morals, nor in contravention of any statute. To hold the undertaking valid and binding is only to compel the defendants to do the thing they bound themselves to do. To hold the hond roid upon a technical construction that it was not a valid statutory bond would ba to leare the plaintifi without the security which it had the right to roly upon at the time it furnished the labor and materials." Union Shect Metal Works v. Dodge, supra note 12.

A bond may be operative as a statutory bond even though the obligee named therein is not the one specified by the statute. Board of Education v. Grant, 107 Mich. 151, 64 N. W. 1050 (IS95); Stephencon v. Monmouth II. \& MI. Co., 84 Fed. 114 (C. C. A. 6th, 1897); Thrig v. Seatt, 5 Wash. 584, 32 Pac. 466 (1893); Huggins v. Sutherland, 39 Wash. 502, 82 Pac. 112 (1905) ; Road Supply \& M. Co. v. Kansas C. \& S. Co., 121 Iian. 299, 246 Pac. 503 (1926) (held operative in favor of third partics, whethes "regarded as a mere common law bond" or a statutory one).

${ }^{16}$ Equitable Sur. Co. v. McMillan, 234 U. S. 448, 34 Sup. Ct. 803 (1913); Illinois Sur. Co. v. John Davis Co., 214 U. S. 376, 37 Sup. Ct. 614 (1917) (collecting other Supreme Court cases); Attna Indem. Co. v. Indionapolis II. \& F. Co., 178 Ind. 70, 98 N. E. 706 (1912); Getchell IIfg. Co. v. Pcterson, supra. note 12; Standard A. \& R. Co. v. Texas Bldg. Co., 99 Kan. 567, 162 Pac. 299 (1917) ; Kansas City v. Schroeder, 196 Mo. 281, 98 S. W. 405 (1906) ; School Dist. v. Livers, 147 Mo. 580, 49 S. W. 507 (1398); Doll v. Crume, supra note 12; cf. International Trust Co. v. Keefe MI. \& I. Co., 40 Colo. 440, 91 Pac. 915 (1907) (obligee can discharge before assent by beneficiary).

In Kansas City H. P. Brick Co. v. National Sur. Co., 157 Fed. 620 (W. D. Me. 1907) ; National Sur. Co. v. Kansas City H. P. Bricls Co., 73 Kan. 196, S4 Pac. 1034 (1906); National Sur. Co. v. Wyandotte C. \& L. Co., 76 Kan. 914, 92 Pac. 1111 (1907) scmble. 
recoiver on the bond; mere constructive notice does not nullify his right against the surety. ${ }^{18}$

There are numerous cases holding that laborers, materialmen, and other subcontractors have no enforceable right against the surety, even though the terms of the principal contract make it the duty of the contractor to pay the third parties, and even though the surety bond is expressly conditioned on full performance of all his promises by the contractor. ${ }^{10}$ Indeed, in some

18 Bell v. Kirkland, 102 Minn. 213, 113 N. W. 271 (1907); Kansas City Brick Co. v. National Sur. Co., 149 Fed. 507 (C. C. W. D. Mo. 1906); National Sur. Co. v. Wyandotte C. \& I. Co., supra note 17; Kansas "City v. Schroeder, supra note 16.

19 Federal Sur. Co. v. Minneapolis S. \& M. Co., 17 F. (2d) 242 (C. C. A. 8th, 1927). (no duty owed by promisee to the plaintiff); Maryland Cas. Co. v. Johnson, 15 F. (2d) 253 (W. D. Mich. 1926) ("to conclude that the clause was inserted for protection of third parties is to indulge an unwarranted confidence in the altruistic motives of those engaged in construction work; . . . indicative of judicial paternalism"); Southorn Sur. Co. v. U. S. Cast Iron Co., 13 F. (2d) 833 (C. C. A. 8th, 1926) (mero indemnity) ; Eureka Stone Co. v. First Christian Church, 86 Ark. 212, 110 S. W. 1042 (1908); Carolina Poyt. Cem. Co. v. Carey, 145 La. 773, 82 So. 887 (1919); Moore v. Mann, 130 Minn. 318, 153 N. W. 609 (1915); Jefferson v. Asch, supra note 3 (duty of promisee to third party required); Uhrich v. Globe Surety Co., 191 Mo. App. 111, 166 S. W. 845 (1915) (the contract is poorly interpreted, the court thinking that as the property was subject to lien the bond was solely for protection of the promisee against liens); Eau Claire Lumber Co. v. Banks, 136 Mo. App. 44, 117 S. W. 611 (1909) (failed as technical statutory bond, and gave no right as private bond because nothing to show intent to give thixd party right); Standard Gas Power Corp. v. New Eng. Casualty Co., 90 N. J. L. 570, 101 Atl. 281 (1917) (held to be indemnity only); Pankey v. National Sur. Co., 115 Ore. 648, 239 Pac. 808 (1925); Parker v. Jeffery, 26 Ore. 186, 37 Pac. 712 (1894) (but see the subseguent third party beneficiary statuto); Greene Co. v. Southem Sur./Co., 292 Pa. 304, 141 Atl. 27 (1927); First M. E. Church v. Isenberg, $246 \mathrm{~Pa}$. 221, 92 Atl. 141 (1914) (obligors on bond specifically bound themselves to payment of materialmen); Lancaster v. Frescoln, 192 Pa. 452, 43 Atl. 961 (1899) 203 Pa. 640, 53 Atl. 508 (1902); Oak Cliff I. Co. v. American Indem. Co., 266 S. W. 429 (Tex. Civ. App. 1924) (bond conditioned on payment of laborers and materialmen held to be indemnity of promisee only); General Bonding Co. v. Waples L. Co., 176 S. W. 651 (Tex. Civ. App. 1915); Nat'1 Bank v. Gulf C. \& S. F. R. R., 95 Tex. 176, 66 S. W. 203 (1902) (same condition interpreted not to be a promise for benefit of third parties); Blyth-Farco Co. v. Free, 46 Utah 233, 148 Pac. 427 (1915) (bond was given to "indemnify and save harmless" the company, and contractor was, by contract, required to pay laborers and materialmen); Smith v. Bowman, 32 Utah 33, 88 Pac. 687 (1907) (bond given to protect against

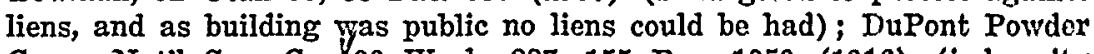
Co. v. Nat'l Sur. Co., 90 Wash. 227, 155 Pac. 1050 (1916) (indemnity only, distinguishing statutory bonds on public contracts); Spokane Merch. Ass'n v. Pacific Sur. Co., 86 Wash. 489, 150 Pac. 1054 (1915); Rust v. U. S. Fidelity \& G. Co., 87 Wash. 93, 151 Pac. 248 (1915); Armour \& Co. v. Western Con. Co., 36 Wash. 529, 78 Pac. 1106 (1905).

"It is earnestly urged that, since there could be no lien on the cemetery" 
of the cases the bond is specifically conditioned on payment of the debts for labor and material. These cases at times evince a fondness for the supposed common law rule requiring "privity;" some cases rest upon the false but still lingering idea that the third party's right depends upon there being some preexisting duty owed to him by the promisee, thus explaining why the promisee came to make a contract requiring payment to the third party; and in other cases the court interprets the contract as solely for the indennity of the promisee. On the last of these three grounds, a few of the cases may possibly be reconciled with the majority cases; but in most of them the facts and the terms of the contract afford no reasonable basis for distinction. Cases where such a distinction by interpretation of the contract was reasonable are collected in the succeeding section.

Does the surety in fact promise to pay the third partics? In the case of a surety bond given to an owner to assure performance of a building contract, the legal duties of the surety ought not to be expanded beyond the terms of the surety's promise. He is paid for his undertaking; but he is not paid for more than his undertaking. The extent of this undertaling is to be determined not only by the surety's words of express promise, but also by the "condition" of the bond. Words of "condition" are not words of "promise" in form; but in the case of a penal bond they must be construed to be words of promise, inasmuch as the only express words of promise are those in which payment of the penal sum is promised. The alternative seems to be between enforcing the penalty and construing the words of condition as a promise and enforeing that. The courts have adopted the latter alternative, penalties no longer being collectible. A bond conditioned to be void on fulfilment by the principal contractor of all of his duties is operative as a promise either that all those duties will be performed, or that the promisee will be indemnified within the limit of the penalty in case of non-performance. The cases denying a remedy to third persons on a private surety bond nearly always interpret it as exclusively the latter promise and rest the decision on that ground.

the parties to the bond must have intended thereby to secure payment to those supplying material and work therefor, as neither they nor the contractors would, without right of lien, or to execution on judgment, undertake to supply materials or work for the premises; also that the marble company knew of and contracted with reference to and on the faith of the security of the bond. The stipulation does not indicate whether or not it had such knowledge, nor would these considerations make any difference in the legal relations." United States Fidelity \& Guar. Co. v. Vermont Marble Co., 16 F. (2d) 83 (C. C. A. 7th, 1926). 
A promise to indemnify the promisee against loss is one that could be fully performed, in many instances, without paying anything to the third persons. ${ }^{20}$ Even if they have power to put a lien on the promisee's property, they may not do so in fact, or the lien that is put on may be disposed of otherwise than by paying the debt. Such a promise therefore cannot surely be said to have been "intended" for the benefit of the third persons, since the promised performance will not necessarily benefit them. And to give the third party a judgment for his debt would often compel the surety to do more than he promised to do.

If on reasonable interpretation the surety bond contains no promise to pay laborers and materialmen, of course they have no right against the surety. There are numerous cases, even in states where the rights of third party beneficiaries are fully recognized, holding that the particular bond in suit contained no promise to pay the third parties who were suing. ${ }^{21}$ These cases show the usual variation in liberality or strictness of interpretation; but the current of authority now is that the contract of a compensated surety is to be interpreted liberally in the interest of the promisee and beneficiaries, rather than strictly in favor of the surety. Some of the older cases, interpreting the bond narrowly and strictly in favor of the surety, are explainable on the ground that the surety was not compensated and the growth of the commercial suretyship business had not then taken place. ${ }^{22}$

The words used in building contracts and in accompanying surety bonds are now usually such that they are, and should be, interpreted as a promise by the surety to pay laborers and

20 Thus, in United States F. \& G. Co. v. Vermont Marble Co., supra. note 19 , the promisee was already saved harmless. The property involved was not subject to lien; and hence the materialman was not a "creditor" of the promisee in any sense. His right on the bond, if any, depended wholly upon an expression of intent to secure payment to him; and this was not very obvious.

21 Babcock v. American Sur. Co., 236 Fed. 340 (C. C. A. 8th, 1916) (interpretation altogether too narrow); Searles v. Flora, supra note 4 (interpretation too narrow); Spalding L. Co. v. Brown, 171 Ill. 487,49 N. E. 725 (1898) ; Sterling v. Wolf, 163 Ill. 467, 45 N. E. 218 (1896); Greenfield L. \& I. Co. v. Parker, 159 Ind. 571, 65 N. E. 747 (1002); Hart v. State, 120 Ind. 83, 21 N. E. 654, 24 N. E. 151 (1889); Green Bay L. Co. v. Independent Sch. Dist., 121 Iowa 663, 97 N. W. 72 (1903); Hunt v. King, 97 Iowa 88, 66 N. W. 71 (1896) ; Marquette Bldg. Co. v. Wilson, 109 Mich. 223, 67 N. W. 123 (1896); Smith v. Bowman, supra note 19 (might well have been interpreted otherwise); Montgomery 'v. Rief, 15 Utah 495, 50 Pac. 623 (1897); Electric Appliance Co. v. United States Fid. \& G. Co., 110 Wis. 434, 85' 'N. W. 648 (1901).

22 See Royal Indem. Co. v. Northern Ohio. G. \& S. Co., supra noto 12; Southwestern Port. Cem. Co. v. Williams, supra note 12. 
materialmen in case of default by the contractor. Often the construction contract contains an express promise by the contractor; and the bond is either conditioned expressly on such payment or on full performance by the contractor of all his promises. The third parties are often definitely indicated in that part of the bond specifying the conditions. Words of "condition" are not words of "promise" in form; but in this class of cases it is sound policy to interpret the words liberally in favor of the third parties. In a majority of states, it is already done; and without question the surety's rate of compensation for carrying the risk is sufficiently adjusted to the law. The compensated surety has become an institution that is well suited to carry the risk of the principal contractor's default, whereas individual laborers and materialmen are frequently very ill prepared to carry the risk. The legislatures have recognized this fact, and in the case of public contracts have required surety bonds to protect the third parties. While this has not been done in the case of private construction, and while the courts should not on their own motion put such a provision into a private surety bond, they may well interpret a bond that is expressly conditioned on the payment of laborers and materialmen as being a promise to pay them and made for their benefit. The words reasonably permit it, and social policy approves it. ${ }^{23}$ The court need not strain the words of the bond, as has sometimes been done, to hold that the third persons were not intended as beneficiaries thereof, even though the promisee may have been thinking chiefly of himself when he paid for the bond.2s

For whose benefit is the surety bond coccuted? This is a question of purposes and motives, a question of complexity and difficulty, especially when there are several persons involved whose purposes and motives are not uniform and are frequently not consciously thought out by the men themselves. Whose purpose is important: the promisee's, the principal contractor's, the surety's, or that of the legislature? The full performance promised by the surety will in every case be economically beneficial to the promisee. He gets either the construction work done or money damages in its place. This beneficial performance is undoubtedly his "leading object" of desire. This has caused many courts to say that he caused the execution of the bond for

${ }^{23}$ Korsmeyer P. \& H. Co. v. MicClay, 43 Neb. 649, 62 N. W. 50 (1895), and Lyman $\nabla$. Lincoln, 38 Neb. 794, 57 N. W. 531 (1894), are cases in which the words of "condition" were liberally construed as a "promise."

${ }^{24}$ If the promisee's property was under no liability to a lien, this fact is evidence that the provision in the bond was intended for the benefit of third persons. See Southwestern Port. Cem. Co. r. Williams, suprs note 12. 
his own benefit and not for the benefit' of third parties. Payment by the surety to the laborers and materialmen will also be economically beneficial to the promisee in those cases where these persons have power to put a lien upon the promisee's property. Payment will extinguish the power and prevent the lien. In procuring such a bond, therefore, the promisee may have been motivated by a desire for this result.

If the case is such that no lien is possible and the promisee knows it, he will not be so motivated and the payment made to the third parties will not be economically beneficial to the promisee. In such a case what motivated the promisee in buying a promise to pay the third persons? Not a desire for his own protection, it has been said, since he is under no duty or liability and the principal contractor's failure to pay the third persons will do him no direct harm. It is not unreasonable to draw the inference, as some courts have done, that his motive was a desire to give added security to the third persons. ${ }^{25}$ But:

- even when the promisee has no duty to the third persons and his property is under no liability to a lien, it is very generally recognized that he has something to gain from giving security to laborers and materialmen upon whom the cost and quality of the construction work largely depend. If they are held to have a right on the bond, it brings them added security; such added security for them is economically beneficial to the promisee as well, in that the shifting of the risk of non-payment from the laborers and materialmen to the surety will tend to the standardization of prices and wages and also of the quality of labor and materials. ${ }^{26}$ In all cases, therefore, whether public

25 "The intention of the parties must control the interpretation of the contract and such intention must be gathered from the whole instrument. To hold that the bond in question was not intended for the protection of third persons would be to say that its second clause is meaningless and for all practical uses should be stricken from the instrument. One of tho canons of construction is that, if possible, effect must be given to all parts of the instrument. On defendant's theory what effect could bo given the obligation 'to deliver the work . . . free from all debts or liens of every character on account of materials furnished or labor performed?' This being a public building no debts made by the contractor could become a lien or charge on the building or impose any liability on the board. So far as the protection of the building and of the board was concerned those words were superfluous; but they were pregnant with meaning if their purpose was to benefit third persons." La Crosse Lumber Co. v. Schwartz, supra note 12.

28 "Taking it as a cold-blooded business proposition, this clause in the bond would natuxally encourage subcontractors of the best sort to take contracts to do certain parts of the work; it would tend to provent the abandonment of the work by mechanics not promptly paid their wages by the contractors, who might be suspected to be of doubtful financial solvency; it would procure the best work and material, and the prompt services of all workers and subcontractors; and all of this would redound 
or private, the motive of the promisee may have been his own economic gain.

But after all, what difference does it make what were the promisee's complex and uncertain purposes or motives? Often he does not know them himself. It should be enough that the contract contains a valid promise that the third persons shall be paid. If there is doubt that such a promise was in fact made, it may be of some assistance to probe into the heart and the history of the promisee. It may help occasionally in identifying the third persons and in interpreting the words of the contract. In most cases there is little difficulty in identifying the third persons to be paid or in determining whether or not the surety promised to pay them. But the third party's right is not dependent upon the promisee's motives. The question is, was payment to him the factual result agreed upon; was it the promised performance? ${ }^{27}$ If it was, judgment in favor of the third party is a proper method of reaching that result. The purposes of the promisee, whatever they were, will be attained with sufficient certainty. The expectations of the third party will not be disappointed. The interests of the public at large in distributing the risks of misfortune and in the realization of hopes will be protected.

In some bonds there is found an express statement that it is

to the benefit of the public. It must be borne in mind that the mechanics, materialmen, and laborers could have no lien upon the building, and that the trustees, representing the state, would not be bound to reserve money with which to pay their claims; but they would have to depend upon the contractor alone. Taling these things into consideration, the bond, in a way, supplied the place of the mechanics' lien law, and thus gave an additional security to all persons working upon this building and supplying material therefor; and this alone was, in our opinion, of the highest importance to the state" National Surety Co. v. Hall-Niller Decorating Co., 104 Miss. 626, 61 So. 700, 46 L. R. A. (N. S.) 325 (1913).

"Was it intended as security for those furnishing labor or materinl for the construction of the building? It is stipulated in the agreemcnt 'that the party of the second part further covenants and agrees to promptly pay for all labor and materials used'. . . Who then were to be paid? Manifestly those furnishing the labor and materials. The provision was for their benefit. No purpose other than this could have been served by the city, for in no event would it have been liable therefor. The evident object was to secure subcontractors to the end that they, lnowing they were secured, would do better work and furnish better material than if they felt uncertain about their pay." Hipwell v. National Surety Co., supra note 12.

${ }^{27}$ That an intention that the plaintiff shall be paid is enough to satisiy the requirement that the contract shall be made "for the benefit" of the plaintiff is recognized in some cases. "If the contract be to pay a debt due to a third person, presumably it is for his benefit unless it appears that the contract was not so intended." Concrete Steel Co. v. Illinois Sur. Co., supra note 12. 
the purpose of the contracting parties to give security to the third parties described as well as to the promisee. ${ }^{28}$ It may even be provided that the third persons shall have a right of action in case of non-payment. Such statements should not be necessary in order to create a right in a third party; but they show definitely the legal relations that the parties intend to create.

Is the bond beneficiary a creditor or a donee? If the surety bond is one that is held to create rights in the laborers and materialmen, they should be classified among creditor beneficiaries wherever that is believed to make any difference. This is because in all cases they are creditors of the principal contractor and the promised payment comes to them in satisfaction of the debt. The promised money, therefore, does not come to them as a gift.

These third persons are not, in a narrow sense of the term, creditors of the promisee. The principal contractor to whom they sell their wares or labor is indebted to them; but the promisee is not. If the surety really promises that they shall be paid, it is a promise of $A$ to $B$ to pay $C$ 's debt to $D$. But in a broader sense, the third persons may be regarded as "creditors" in those cases where they have a power to subject the promisee's property to a lien. As against the principal contractor, they have a right and he has a duty to pay. As against the promisee, they have a power to affect his beneficial property relations and he has a liability that his property may be so affected.20 Assuming once more that the surety has really promised to pay the third persons, we have not only a promise by $A$ to $B$ to pay $C$ 's debt to $D$, but also a promise by $A$ to $B$ to discharge $B$ 's "liability" to $D$. Under these circumstances, it is not unreasonable to place the third persons in the category of creditor beneficiaries.

In the non-lien cases, where the promisee is under neither duty nor "liability" to the third persons, but the surety nevertheless by reasonable interpretation promises that they shall be paid, such persons are donees of the promise but are not donees of the promised payment. Payment by the surety comes to them at the cost of their claim against the principal con-

${ }^{28}$ See Oak Cliff L. Co. v. American Indem. Co., supra noto 19, citing Texas cases.

29 After the lien has been created by compliance with the mechanics lion law, the laborer has more than a power; he has a "lien," a limited property interest, like other such interests involving rights and other rolations as well as powers. The promisee has a correspondingly smaller proporty. interest; his property rights, powers, privileges and especially his immunities have been considerably decreased. This does not cause us to say, however, that the promisee has come under an obligation (duty) to pay the laborer. 
tractor, although not at the cost of their power to file a lien, for they have no such power; payment therefore is no gift. But the promise of the surety, the new security consisting of a right against the surety, comes to the third persons at no cost to them. This is true of practically all creditor beneficiaries as well as donee beneficiaries.

In all these cases alike the laborer or materialman gets one thing for nothing and that is "security." This is the legal "right" itself. His own contract created only a right against the principal contractor; in consideration for that he gave his labor and materials. His right on the surety bond comes to him as an additional security by donation. He gives nothing for it, except that in the gradual adjustment of prices and wages his compensation tends to become smaller as the risk of nonpayment is thrown upon a commercial surety.

Statutory surety bonds. It is frequently provided by statute that in the case of contracts for public works the contractor shall give a bond not only to indernnify the municipality for breach but also to assure payment to sub-contractors, materialmen, and laborers..$^{30}$ When such a bond is executed in conformity with the statute, it is enforceable against the surety by the third party beneficiaries described. ${ }^{M}$ Questions of "privity" are eliminated; but "intention to benefit" may not be, since the

30 For illustrative statutes see the following: 33 Stat. 811 (1905), 10 U. S. C. $\$ 270$ (1928) ; ARK. Dig. STAT. (Crawiord \& Moses, 1921) $\$ 6913$; CAI. Code of Crv. Proc. (Deering, 1923) § 1203.

31 Illinois Sur. Co. v. John Davis Co., supra note 16; Southwestern P. Cement Co. v. MIcElrath Con. Co., 11 F. (2d) 910 (Ct. of App. D. C. 1925); Aetna C. \& S. Co. v. Henslee, 163 Ark. 492, 260 S. W. 414 (1924) ; Carpenter v. Furrey, 128 Cal. 665, 61 Pac. 369 (1900); Southern Sur. Co. v. Dawes, $161 \mathrm{Ga}$. 207, $130 \mathrm{~S}$. E. 577 (1925) (statute authorized action by materialman); Aetna Indem. Co. v. Indianapolis $\mathrm{MT}$. \& F. Co., 178 Ind. 70, 98 N. E. 706 (1912); Standard A. \& R. Co. 下. Texas Bldg. Co., 99 Kan. 567, 162 Pac. 299 (1917); MicNamara v. MicGuire, 254 Miass. 589, 150 N. E. 862 (1926); Sampson Co. v. Commonwealth, 202 Mass. 326, 88 N. E. 911 (1909) (the statute prescribed no mode of enforcement, and the court held that a petition in equity joining all parties to the bond was proper) ; People v. Cotteral, 115 Mich. 43,73 N. W. 19, 74 N. W. 183 (1897); Village of West Duluth v. Norton, 57 Minn. 72, 58 N. W. 829 (1894); St. Louis v. Hill Const. Co., 175 Mo. App. 555, 158 S. W. 98 (1913); Ingold v. Hickory, 178 N. C. 614, 101 S. E. 525 (1919); Donaldson v. Benight, 105 Okla. 108, 232 Pac. 116 (1924); School District v. Alameda Const. Co., 87 Ore. 132, 169 Pac. 507, 788 (1918); Lancaster v. Frescoln, supra note 19; semble; Baum v. Whatcom Co., 19 Wash. 626, 54 Pac. 29 (1898).

The rule applicable to "statutes" applies also where a municipal charter or city ordinance requires the bond. Fite v. Pearson, 215 Ala. 521, 111 So. 15 (1927); Morton v. Power, 33 Minn. 521, 24 N. W. 194 (1S85); Wilson v. Whitmore, 92 Hun 466, aff'd, 157 N. Y. 693, 51 N. E. 1094 (1S9S); Philadelphia v. Nichols Co., supra note 15. 
statute may itself make that the test. ${ }^{32}$ The statute ustially indicates, however, the classes of third persons for whose protection the statute was passed; and the "intention" of the legislature is substituted for the "intention" of the parties.

Questions arise, also, as to the exact limits of the class of persons who are within the protection of the statute and as to the character of claims which the surety is bound to pay..$^{\text {ga }}$ These questions must be answered according to the usual rules of statutory interpretation. The statute may specify laborer's and materialmen; but what labor and materials are included? Usually the materials must have been incorporated into the structure required by the principal contract; and yet blasting powder consumed in excavation has been included, ${ }^{34}$ while money loaned to the contractor to pay for labor and materials has not been. ${ }^{35}$ Those who supply tools and appliances to the contractor are not ordinarily protected, whether they sell or hire; ${ }^{\text {sa }}$ these

32 Some statutes expressly state that, if a public bond be given, any party intended to be benefited may sue. In such case, of course, an "intended" beneficiary may sue. Hay v. Hassett, supra note 12.

33 Under the federal statute the surety owes no duty to a person tortiously injured by the contractors; the statute indicates the third party beneficiaries expressly, and persons injured by tort are not included. United States v. Mass. Bonding \& Ins. Co., 18 F. (2d) 203 (C. C. A. 6th, 1927). The Iowa statute was similarly construed in Schisel v. Marvill, 198 Iowa 725, 197 N. W. 662 (1924).

The Michigan statute is construed not to include "subcontractors." People v. Cotteral, supra note 31; Avery v. Ionia Co., 71 Mich. 538, 39 N. W. 742 (1888). As to who is a "subcontractor" as opposed to a "materialman" see People v. Powers, 108 Mich. 339, 66 N. W. 215 (1896); People v. Collins, 112 Mich 605, 71 N. W. 153 (1897); People v. Thompson, 110 Mich. 21, 77 N. W. 314 (1898) ; People v. National Const. Co., 159 Mich. 133, 123 N. W. 801 (1909).

34 National Sur. Co, v. United States, 228 Fed. 577 (C. C. A. 6th, 1916); Sampson Co. v. Commonwealth, supra note 31; Hercules Powder Co. v. Knoxville etc. R. R. Co., 113 Tenn. 382, 83 S. W. 354 (1904).

35 Southern Sur. Co. v. Holden L. \& L. Co., 14 F. (2d) 411 (C. C. A. 8th, 1926) ; United States v. Rundle, 107 Fed. 227 (C. C. A. 9th, 1901); Oliver Const. Co. v. Crawford, 142 Miss. 490, 107 So. 877 (1926).

3e National Surety Co. v. United States, 228 Fed. 577 (C. C. A. 6th, 1916) (soap, towels, stovepipe, rat traps, material for outfitting a boarding houso for laborers, material for repairing boats and machines, drilling machines; rev'd, as to board of laborers in Brogan v. National Sur. Co., 246 U. S. 257, 38 Sup. Ct. 250 (1918)) ; Pierce Oil Corp. v. Parker, 168 Ark. 400, 271 S. W. 24 (1925) (gasoline used in running a truck used in hauling materials) ; Heltzel Steel Form \& I. Co. v. Fidelity \& D. Co., 168 Ark. 728, 271 S. W. 325 (1925); Royal Indem. Co. v. Day, 114 Ohio St. 58, 150 N. E. 426 (1926) (rental of a concrete mixer and hoisting engine); Southern Surety Co. v. Municipal Ex. Co., 61 Okla. 215, 160 Pac. 617 (1916). (rental of a trenching machine); United States Rubber Co. v. Washington Eng. Co., 86 Wash. 180, 149 Pac. 706, L. R. A. 1915F 951; Standard Boiler Wks. v. National Sur. Co., 71 Wash. 28, 127 Pac. 573, 43 L. R. A. (N. S.) 162 (1912) (repairing work on a steam shovol); 
are not incorporated and are usually not entirely consumed on the job. A claimant has been held to be not within the protection of the statute merely because his labor or material has entered into the preparation of materials for a building. The part he played may be too remote: for example, labor at a quarry from which rock is taken for a structure, the repair of cars used in carrying such rock, wages of men who drove holses pulling the cars that carried the rock.37 The federal statute, on the other hand, has been construed to include these very items. $^{3 s}$ Labor and materials supplied to a subcontractor instead of the principal contractor, but going directly into the performance of the principal contract, are generally held to be within the protection of the statutory bond. ${ }^{39}$

Wisconsin Brick Co. v. National Sur. Co., 164 Wis. 585, 160 N. W. 1044 (1917) (freight charges for transporting material). But in IIultnomah Co. v. United States Fid. \& Guar. Co., 87 Ore. 19S, 170 Pac. 525 (1918), rent of a caterpillar engine hired by a subcontractor was held within the statute. And "labor" has been held within the bond even though it ras done by means of horses, tractors, derricks, and laborers on behalf of the elaimant. French v. Powell, 135 Cal. 636, 68 Pac. 92 (1902); Fulghum r. State, 109 So. 644 (Fla. 1926).

${ }^{37}$ In American Guaranty Co. v. Cincinnati Iron \& S. Co., 115 Ohio St. 626,155 N. E. 389 (1927), the court said: "The test of remoteness which will defeat recovery under our statute does not lie in the relationship of the various claimants in and of itself; it lies in the requirement that the materials in question must have entered into the erection."

ss The federal statute has been interpreted very widely so as to include many things within the phrase "labor and materials in the prosceution of the work." Brogan v. National Surety Co., supra note 36; (board furnished for laborers) ; Title Guaranty Co. v. Crane, 219 U. S. 24, 31 Sup. Ct. 140 (1910) (cartage and towage of material and drawings for malking molds for castings) ; United States Fid. \& Guar. Co. v. United States, 231 U. S. 237, 34 Sup. Ct. 88 (1913) (labor at a quarry 50 miles from the brealwwater being built, and repairing of the cars carrying the stone); Illinois Surety Co. v. John Davis Co., supra. note 16 (rental of cars, track and cquipment, e:pense of loading, and freight).

39 United States v. American Surety Co., 200 U. S. 197, 26 Sup. Ct. 168 (1906); Williams v. Tingey, 26 Cal. App. 574, 147 Pac. 584 (1915); Grifith v. Stucker, 91 Kan. 47, 136 Pac. 937 (1913); Nash r. Commonwealth, 174 Mass. 385, 54 N. E. 865 (1899), 182 Miss. 12, 64 N. E. 690 (1902); Combs v. Jackson, 69 Minn. 336, 72 N. W. 565 (1897) ; Duby r. Jackson, 69 Minn. 342,72 N. W. 568 (1897); St. Louis v. Hill-O'MIeara Con. Co., 175 Mo. App. 555, 158 S. W. 98 (1913); Jackson Co. v. Freeborn Eng. \& Con. Co., 174 Mo. App. 28, 160 S. W. 271 (1913); Strong v. American Fence Const. Co., 245 N. Y. 48, 156 N. E. 92 (1927); Philadelphia v. Wiggins, $227 \mathrm{~Pa} .343,76$ Atl. 31 (1910) ; Philadelphia v. Nichols Co., st?pra note 15; Bowditch v. Gourley, $24 \mathrm{~Pa}$. Super. Ct. 342 (1904); Gilmore v. Westermon, 13 Wash. 390, 43 Pac. 345 (1896).

In American Guaranty Co. v. Cincinnati Iron \& S. Co., supra note 37, the plaintiff supplied steel ready for a building to a materialman who had contracted with the principal building contractor, and the plaintiff was held to be a "materialman" within the meaning of the stature. 
Where the bond that is executed is not in conformity with the statute and omits the provision for protection of third parties they will ordinarily be held to have no rights against the surrety, whose obligations are not extended beyond the terms of the bond executed by him. ${ }^{40}$ The statute may go so far, however, as to declare in express words that such surety bonds are to be regarded as incorporating the provisions of the statute even though the express words of the bond omit such provisions. A statute of this type is of a remedial character for the special protection of those who furnish labor and materials on public contracts and is to be liberally construed. Sureties have notice of the statute and will be held in accordance with its provisions.11 Statutory provisions have been read into a bond even though the statute did not expressly require it, ${ }^{42}$ and even though the bond expressly provided that the surety should owe no duty to anyone other than the named obligee.43

It has been held in New York that a laborer cannot maintain a separate action on a surety bond of the sort here discussed, because the bond is given primarily for the benefit and protection of the state or municipality, and that such protection might be lost if third parties should be allowed to bring suits tending to exhaust the amount of penalty of the bond.44 The court said:

\footnotetext{
40 McCausland \& Co. v. Brown Const. Co., 172 N. C. 708, 00 S. T. 1010 (1916) ; Aetna Casualty \& S. Co. v. Leathers, 33 Ga. App. 444, 126 S. T. 881 (1924); Eau Claire-St. Louis Lumber Co. v. Banks, 136 Mo. App. 44, 117 S. W. 611 (1909); cf. United States v. Starr, 20 F. (2d) 803 (C. C. A. 9th, 1927).

11 Southern Surety Co. v. Chambers, 115 Ohio St. 434, 154 N. E. 786 (1926); American Guaranty Co. v. Cincinnati Iron \& Steel Co., silpra note 37 .

A statutory provision that a bond given under the statute shall protect the claims of laborers and materialmen, whether such provision be incorporated in the bond or not, will be given effect. See Standard Elcctric Time Co. v. Fidelity \& Deposit Co., 191 N. C. 653, 132 S. E. 808 (1926) construing Public Laws N. C. 1923 , c. 100.

12 Nye-Schneider-Fowler Co. v. Roeser, 103 Neb. 614, 173 N. W. 605 (1919); School Dist. v. Alameda Const. Co., 87 Ore. 132, 169 Pac. 507, 788 (1918); Gill v. Paysee, 48 Nev. 12, 226 Pac. 302 (1924); Globe Indomnity Co. v. Barnes, 281 S. W. 215 (Tex. Civ. App. 1926); Southern Surety Co. v. Klein, 278 S. W. 527 (Tex. Civ. App. 1920); Fogarty v. Davis, 305 Mo. 288, 264 S. W. 879 (1924).

"The bond executed does not technically conform to the langunge of the statute. However, in spirit, it manifests a purpose and intention to do so. I am satisfied that the statute of 1913 must be read into tho bond in question." Coleman, J., in Gill v. Paysee, supra.

43 Hartford Acc. \& Indem. Co. v. Board of Education, 15 F. (2d) 317 (C. C. A. 4th, 1926) ; Ingold v. Hickory, supra note 31; Globe Indom. Co. v. Barnes, supra note 42.

44 Fosmire v. National Surety Co., 229 N. Y. 44, 127 N. E. 472 (1920), citing Eastern Steel Co. v. Globe Indem. Co., 227 N. Y. 586, 125 N. E. 917
} 
"We put our decision upon the single ground that the bond, read in its entirety, is inconsistent with an intention that the plaintiff and others in like position should have a right to sue upon it......The dominant purpose of this bond was protection to the state..... This dominant purpose will be defeateo if laborers may ignore the people and sue in their own right. They may then sue for wages as often as there is default, and, exhausting the penalty of the bond, leave nothing for the state."

The argument of the court is not entirely convincing. There was no showing in the particular case that the state had any claim or that the penalty of the bond was likely to be exhousted; and the state might well be left to look after its own interests in the matter. It is true, however, that there were some differences between this case and others apparently contra. In this case a statute required a bond for the protection of the state but did not require the bond to protect laborers; the provision in the bond in favor of laborers was put in without legislative command. It may well be that the plaintiff would have been given judgment if he had joined the state as a party to the action and had shown that the state's interests were not imperilled. In a later case the same court held that a materialman could recover where a statute expressly required a bond for his benefit, and that the judgment would be for the full amount of the claim unless the defendant showed that there were other claims that would make a total in excess of the penalty of the bond. ${ }^{15}$

(1919) ; Buffalo Cement Co. v. MicNaughton, 90 Hun 74, affd, 156 N. Y. 702,51 N. E. 1089 (1898).

The federal statute expressly provides that the United States shall have a preferred claim and also that all laborers and materialmen must join in a single suit against the surety, brought not later than twelve months after final settlement with the United States. If the penalty of the bond is not sufficient to pay all such claimants, they share pro rata. See United States v. Mass. Bonding \& Ins. Co., supra note 3i; Mranlsin v. United States, 215 U. S. 533, 30 Sup Ct. 174 (1910); United States v. IIcCord, 233 U. S. 157, 34 Sup. Ct. 550 (1914); Illinois Surety Co. v. Peeler, 240 U. S. 214, 36 Sup. Ct. 321 (1916); Illinois Surety Co. จ. John Davis Co., supra note 16.

The federal statute in its earlier form did not give any preference to the United States against the surety. United States Fidelity Co. v. StruthersWells Co., 209 U. S. 306, 28 Sup. Ct. 537 (1908); Davidson Marble Co. v. Gibson, 213 U. S. 10, 29 Sup. Ct. 324 (1909).

45 A materialman suing on a statutory bond for his benefit or for damages for failure to give such a bond can recover no more than "the pro rata share that would he his" of the penalty of the bond considering the claims of other beneficiaries. But he makes a prima facie case by proving his own demand. The burden is then on the defendant to produce evidence of other claims that would malie the plaintiff's pro rata share less than the amount of his claim. Strong v. American Fence Const. Co., 245 N. Y. 48,156 N. E. $9 \overrightarrow{2}$ (1927). 
Official bonds and public service bonds. Public officials and persons or companies rendering some kind of public service are often required to give bond to secure individuals affected by the public service against loss caused by default therein. The named obligee is usually the state or municipality or a public trustee. In such cases it is clear that the individuals are the beneficiaries intended to be protected and they experience no difficulty in maintaining suit.6 If the official bond is solely for the protection of the state or municipality, as it is in the case of an official treasurer's bond to secure public funds deposited with him, third persons are not beneficiaries thereof and can maintain no action on the bond. Some official bonds may be for both purposes, in which case what has been said herein concerning contractors' surety bonds would be applicable.

The Pennsylvania court denies third parties an action on a non-statutory surety bond in which there was a promise to pay laborers and materialmen. First M. E. Church v. Isenberg, supra note 19; Board of Education v. Massachusetts B. \& I. Co., 252 Pa. 505, 97 Atl. 688 (1916); Lancaster v. Frescoln, supra note 16 (there was an ordinance authorizing "an additional bond" for third parties but the bond in suit was not such a bond); Greene County v. Southern Sur. Co., supra note 19. It gives the third party a remedy, however, either in his own name or that of the state, on a bond executed in accordance with a statute providing that on public contracts a bond shall be given assuring payment to the third parties specified. The fact that the full penalty of the bond might be exhausted by claims of third parties does not trouble the court, since the protection of these parties is part of the system of protecting the state's intorest. "We see no reason why the State may not use its own bond in any way it may be to its greatest advantage. It is sufficient in this case to know that the liability in this suit does not exceed the amount of tho bond." Commonwealth v. National Sur. Co., 253 Pa. 5, 97 Atl. 1034 (1916); Robertson Co. v. Globe Indem. Co., $268 \mathrm{~Pa}$. 309, 112 Atl. 50 (1920). Thero are numerous other public bond cases to the same effect.

See also Southwestern Port. Cem. Co. v. Williams, supra note 12, at 383: “*** it is manifest that ordinary prudence, exercised by the responsiblo officials in fixing the penalty of the bond, and in supervising the work, may easily avoid any loss, either to the public or to laborers and materialmen."

Under a Massachusetts statute requiring a city to take "sufficient security" for payment of laborers and materialmen on a public contract, not only do the third parties have an enforceable right on the bond against the surety, but their claim takes precedence over that of the city and they may exhaust the penalty of the bond to the exclusion of the city. McNamara v. MeGuire, supra note 31 ("bill in equity").

46 Crawford v. Ozark Ins. Co., 97 Ark. 549, 134 S. W. 951 (1911) (bond to secure holders of insurance policies). 